\title{
STRATEGI GURU DALAM PEMBENTUKAN KARAKTER PEDULI LINGKUNGAN BAGI SISWA
}

\author{
M. Sapriadi ${ }^{1}$, dan Siti Hajaroh ${ }^{2}$ \\ Universitas Islam Negeri Mataram \\ e-mail: 11501060839.mhs@uinmataram.ac.id,_hajaroh.saif@gmail.com
}

\begin{abstract}
Abstrak: penelitian ini bertujuan untuk mengetahui startegi guru dalam pembentukan karakter peduli lingkungan bagi siswa di MIN 2 Lombok Tengah. Penelitian ini merupakan penelitian kualitatif dengan pendekatan deskriptif. Pengumpulan data menggunakan teknik observasi, wawancara dan dokumentasi. Sumber data diperoleh dari kepala sekolah, guru, staf, dan siswa. Teknik analisis data menggunakan reduksi data, penyajian data, dan verifikasi pengamatan, peningkatan ketekunan dan triangulasi. Hasil temuan penelitian antara lain: (1) para guru telah menggunakan startegi yang sangat baik dalam membangun karakter bagi siswa untuk peduli lingkungan. Strategi guru yang dimaksud antara lain, seperti: penetapan jadwal piket kelas, menempelkan gambar tentang kebersihan, menambah sarana pembuangan sampah. Strategistrategi yang telah diterapkan oleh guru dapat menjadikan siswa menjaga lingkungan sekolah/kelas dengan baik. (2) Kepedulian para guru dalam pembentukan karakter siswa peduli lingkungan di MIN 2 Lombok Tengah terlihat dalam bentuk mendekati, dan menasehati siswa, serta terlibat dalam kegiatan gotong royong.
\end{abstract}

Kata Kunci: Pembentukan karakter, peduli lingkungan, madrasah ibtidaiyah

Title: Teacher strategy of character building of environmental care for students'

Author: Sapriyadi

Abstract: This study aims to discuss the teacher's strategy in the character building of environmental care for students in Madrasah Ibtidaiyyah Negeri (MIN: State Islamic Elementary School) 2 Lombok Tengah. This research is qualitative-descriptive research. Data collection uses observation, interview, and documentation techniques. Data sources were obtained from the principal, teachers, staff, and students. Data analysis techniques using data collection, data reduction, data display, and conclusion verification. The findings of the study include: (1) the teachers have used a very good strategy in building character for students to environmental care. The intended teacher strategies include, such as setting class assignments (picket schedule), sticking/putting up posters about cleanliness/keep clean, adding to the means of garbage disposal. The strategies that have been implemented by the teacher can make students maintain a good school/ classroom environment. (2) The concern of the teachers in shaping the character of students caring for the environment in MIN 2 Lombok. Tengah is seen in the form of approaching and advising students, as well as being involved in mutual cooperation activities (gotong-royong).

Keywords: Character building, environmental care, madrasa ibtidaiya (Islamic elementary school)

DOI: https://doi.org/10.20414/jpk.v15i1.1426 


\section{PENDAHULUAN}

Pendidikan karakter adalah pendidikan budi pekerti plus, yaitu yang melibatkan aspek pengatahuan (cognitipe), perasaan (feeling) dan tindakan (action). Karakter adalah cara berpikir dan berperilaku yang menjadi ciri khas tiap individu untuk hidup dan bekerja sama, baik dalam lingkup keluarga, masyarakat, bangsa dan negara. Pembentukan karakter merupakan salah satu tujuan pendidikan nasional. ${ }^{1}$

Dalam pendidikan karakter, terdapat nilai - nilai luhur yang menjadi karakter dari masing-masing domain tersebut, di mana domain pikir mencakup karakter-karakter seperti cerdas, kreatif, kritis, inofatif, ingin tahu, berfikit terbuka, produktif, berorientasi iptek, dan reflektif. Domain hati mencakup karkter-karakter untuk beriman dan bertaqwa, jujur, amanah, adil, bertanggung jawab, berimpati, berani, mengambil resiko, pantang menyerah, rela berkorban, dan berjiwa patriotik. Kemudian, domain raga mencakup karakter-karakter seperti bersih dan sehat, disiplin, sportif, tangguh, andal, bedaya tahan, bersahabat, determinatif, ceria, dan gigih. domain rasa yang meliputi, karakter-karakter seperti ramah, saling menghargai, toleran, peduli, suka menolong, gotong royong, nasionalis, kosmopolit, mengutamakan kepentingan umum. Bangga menggunakan bahasa dan produk indonesia, dinamis, kerja keras, dan beretos kerja. ${ }^{2}$

Sekolah memiliki tanggung jawab untuk peduli terhadap membantu pembentukan karakter dalam lingkungan sekolah. Untuk itu sekolah harus memberikan pendidikan kepada siswa dalam pembentukan karkter di lingkungan sekolah. Dalam proses pendidikan, banyak sekali di jumpai permasalahan yang di alami oleh siswa di lingkungan sekolah, seperti pembentukan karakter untuk peduli lingkungan. Dalam hal ini, permasalahan siswa dalam pembentukan karakter peduli lingkungan harus melalui strategi guru yang akan membantu dalam pembentukan karakter peduli lingkungan terhadap siswa.

Permasalahan sekarang adalah strategi apa yang digunakan oleh guru dalam pembentukan karakter kepedulian siswa untuk lingkungan sekolahnya seperti yang terjadi disalah satu lembaga pendidikan yaitu di sekolah Madrasah Ibtidakyah Negeri 2 Lombok Tengah. Menurut salah satu guru yang ditemui peneliti, bahwa terdapat beberapa strategi yang digunakan guru dalam menjaga kebersihan lingkungan sekolkah salah satunya, membuat jadwal piket kelas untuk menjaga kebersihan lingkungan sekolah serta menambah sarana tempat pembuangan sampah selain itu juga memberikan sangsi bagi siswa yang membuang sampah sembarangn dalam bentuk teguran. Selain itu guru juga mengadakan gotong royong untuk membersihkan halaman sekolah serta menanam bunga bersama. Dalam hal ini peneliti tertarik untuk meneliti lebih dalam strategi yang dilakukan guru dalam membentukan karakter

${ }^{1}$ Masnur muslich, pendidikan karakter (Jakarta: Bumi Aksara, 2014), h. 35

${ }^{2}$ M.Hum \& Muhammad Yaumi Pendidikan Karakter: Landasan, Pilar, dan Implementasi (Jakarta:Premadia Group, 2014), h. 6. 
siswa peduli lingkungan Terkait dengan hal tersebut, peneliti telah melakukan wawancara awal di Madrasah Ibtidaiyah Negeri 2 Lombok Tengah berdasarkan hasil wawancara adalah sebagai berikut:

...."saya sebagai guru kelas 1 memberi bimbingan kepada siswa untuk memenuhi tata tertib sekolah seperti membersihkan ruang kelas dan lingkungannya dan memberi bimbingan kepada siswa sebelum masuk kelas"....

Untuk mempertajam pernyataan guru kelas 1 tersebut, maka peneliti melakukan wawancara dengan salah satu siswa kelas 5 terkait tata tertib sekolah mengenai bimbingan kepada siswa dalam membersihkan ruang kelas, hal ini juga disampaikan oleh salah satu siswa:

“....saya sering disuruh membuang sampah pada tempat pembuangan sampah sama ibu guru dan membersihkan ruang kelas setiap jadwal piket kelas...."4

Berangkat dari hal tersebut peneliti ingin mengatahui lebih dekat bagaimana peran guru di sekolah sebagai salah satu contoh untuk membentuk karakter siswa dalam peduli lingkungan sekolah dan meneliti masalah yang terkait dengan strategi pembentukan karakter peduli lingkungan. Sebagaimana yang dijelaskan dalam Al-quran tentang pentingnya menjaga lingkungan di sekitar kita yaitu :

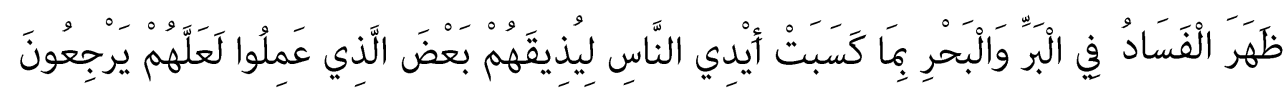

"Telah tampak kerusakan di darat dan di laut disebabkan karena perbuatan tangan manusia; Allah menghendaki agar mereka merasakan sebagian dari (akibat) perbuatan mereka, agar mereka kembali (ke jalan yang benar). Qs: Ar-Rum Ayat: $41 .{ }^{5}$

Dari paparan di atas, menunjukkan pentingnya pembahasan strategi guru dalam pembentukan karakter peduli lingkungan bagi siswa. Artikel ini bertujuan untuk mengeksplorasi bentuk kepedulian dan strategi guru terhadap pembentukan karakter peduli lingkungan bagi siswa di MIN 2 Lombok Tengah.

\section{METODE PENELITIAN}

Penelitian mengambil tempat di MIN 2 Lombok Tengah tepatnya di Desa Jelantik Kecamatan Jonggat Kabupaten Lombok Tengah. Dalam penelitian ini, peneliti akan menggunakan pendekatan kualitatif deskriptif, karena data-data yang akan dikumpulkan adalah data data yang bersifat deskriptif berdasarkan pada fenomena kasus yang akan diteliti yaitu strategi guru dalam pembentukan karakter siswa peduli lingkungan. Dalam penelitian ini, peneliti sebagai instrumen kunci secara langsung akan mengumpulkan data melalui observasi, dokumentasi, wawancara dengan informan kunci di lapangan.

\footnotetext{
${ }^{3}$ Aminah ,Wawancara, Madrasah Ibtidakiyah Negeri 2 Lombok Tengah, 17 Mei 2018.

${ }^{4}$ Linda, Wawancara, Madrasah Ibtidakiyah Negeri 2 Lombok Tengah, 20 Mei 2018.

${ }^{5} \mathrm{QS}$ ar-rum [41]
} 
Kehadiran peneliti bukan ditujukan untuk mempengaruhi subjek penelitian, tetapi untuk mendapatkan data dan informasi yang akurat. Untuk mendapatkan data yang akurat dapat digunakkan bebrapa mmetode, yaitu metode observasi, interview/wawancara, dan dokumentasi. Dalam pelaksanaannya, peneliti hadir di lapangan mulai sejak diizinkan untuk mengadakan penelitian, dengan cara mendatangi lokasi penelitian pada waktu tertentu dan tidak terjadwal secara formal.

Sumber data penelitian adalah subjek tempat asal data dapat diperoleh, dapat berupa bahan pustaka, atau orang (informan atau responden). Sumber orang juga disebut informan terdiri dari Kepala Sekolah, Waka Kesiswaan, Guru Wali Kelas, dan siswa MIN 2 Lombok Tengah. Sumber data utama dalam penelitian kualitatif adalah kata-kata dan tindakkan dengan cara mengambil sampel dari perwakilan siswa-siswi yang akan diteliti untuk dapat mengidentifikasi permasalahan, sejauh mana pelanggaran tata tertib yang dilakukan siswa dan upaya apa yang dipersiapkan peneliti untuk mencari jalan pemecahannya.

Adapun teknik pengumpulan data yang peneliti gunakan dalam penelitian ini adalah:

a. Observasi non-partisipan, karena peneliti tidak terlibat dalam kegiatan sehari-hari orang yang sedang diamati tetapi peneliti berperan sebagai penonton atau melihat terhadap segala aktivitas yang dilakukan oleh siswa. Adapun tujuan peneliti melakukan observasi yaitu agar peneliti tahu apa saja kegiatan yang dilakukan siswa selama berada dilingkungan sekolah, dan supaya peneliti mendapatkan informasi atau data yang lebih lengkap tentang strategi guru dalam pembentukan karakter siswa peduli lingkungan.

b. Wawancara (interview) tak terstruktur. Artinya, peneliti tidak menyiapkan pertanyaanpertanyaan tertulis yang disertai dengan jawabannya, akan tetapi peneliti hanya mempersiapkan kisi-kisi umum dari hal-hal yang ingin ditanyakan kepada informan dan jawabannya pun bisa berkembang setelah berada dilapangan. Metode wawancara ini digunakan untuk memperoleh informasi tentang strategi pembentukan karakter peduli lingkungan di MIN 2 Lombok Tengah tahun pelajaran 2018/2019.

c. Metode Dokumentasi merupakan suatu cara pengumpulan data yang menghasilkan catatan-catatan penting yang berhubungan dengan masalah yang diteliti, sehingga akan diperoleh data yang lengkap, sah dan bukan berdasarkan perkiraan. Dengan demikian penggunaan metode dokumentasi ini untuk memperoleh data-data yang tertulis, seperti sejarah berdirinya MIN 2 Lombok Tengah, data jumlah siswa dan data pegawai atau guru MIN 2 Lombok Tengah tahun pelajaran 2018/2019

Analisis data menggunakan teknik analisis data Bogdan yakni Data Reduction (Reduksi data), Data Display (penyajian data), dan Conclusion Drawing/Verification. Untuk membuktikan adanya kesesuaian antara data yang diteliti dengan kenyataan, maka diperlukan keabsahan data dan temuan, sehingga data menjadi valid. Keabsahan data ini bertujuan untuk 
membuktikan bahwa apa yang diamati oleh peneliti sesuai dengan apa yang sesungguhnya ada dalam kenyataan. Usaha peneliti untuk memperoleh keabsahan data dengan teknik triangulasi dan perpanjangan waktu penelitian.

Peneliti gunakan triangulasi metode, yang mana triangulasi metode merupakan proses membandingkan hasil wawancara dengan hasil pengamatan observasi. Hal ini digunakan untuk mengetahui kesesuaian antara hasil wawancara dengan hasil pengamatan atau observasi yang peneliti lakukan, sehingga data yang ditemukan terdapat kesesuaian antara apa yang ditanyakan dengan yang diamati langsung.

Perpanjang keikutsertaan juga menuntut agar peneliti terjun ke lokasi dan dalam waktu yang cukup panjang guna mendeteksi dan memperhitungkan distorsi (penyimpangan) yang mungkin mengotori data. Perpanjangan keikutsertaan juga dimaksudkan untuk membangun kepercayaaan peserta subjek terhadap peneliti dan juga kepercayaan diri peneliti sendiri.

\section{HASIL TEMUAN DAN PEMBAHASAN}

\section{Strategi Guru dalam Pembentukan Karakter Siswa}

Pendidikan merupakan proses sosialisasi anak yang terarah dengan hakikat pendidikan sebagai proses pengoprasian ilmu yang normative akan memberikan warna kehidupan sosial yang berbeda dari masa kemasa. Pendidikan dari arti luas harus diartikan bahwa perkembangan anak dipengaruhi oleh kehidupan keluarga, masyarakat dan kelembagaan. Dalam ruang lingkup sekolah siswa bukan saja dikenalkan dengan norma-norma lingkungan terdekat, tetapi dikenalkan terhadap norma bangsa, antar bangsa, etika pergaulan dan pendidikan moral diajarkan secara terprogram dengan tujuan untuk membantu perilaku kehidupan bermasyarakat dan berbangsa. ${ }^{6}$

Tugas seorang guru bukan hanya mengajarkan materi pembelajaran yang diajarkan sesuai dengan apa yang diminta dalam sebuah buku akan tetapi guru juga ditugaskan untuk bisa merubah karakter siswa mengubah perilaku siswa dari yang tidak baik menjadi baik dan yang baik bisa menjadi lebih baik lagi, terlebih lebih diusia anak-anak yang masih kecil dan guru MI yang harus berkerja keras untuk membentuk karakter siswa menjadi anak yang baik, memberikan pembelajaran dari angka 0 sampai 100.

Sesuai dengan paparan data dan temuan pada bab sebelumnya maka dalam bab ini akan diuraikan dalam penafsiran terhadap apa yang diperoleh dari lapangan penelitian yang meliputi dua konteks, yaitu: strategi guru dalam pembentukan karakter siswa, dan kepedulian guru dalam pembentukan karakter siswa peduli lingkungan di MIN 2 Lombok Tengah. Dari hasil penenlitian akan diberi penafsiran dan diintegrasikan dengan kumpulan pengatahuan 
yang telah mapan, sedangkan hasil penelitian yang tidak dapat teori pembandingannya akan diuraikan sesuai dengan hasil yang ditemukan dilapangan.

Adapun strategi guru dalam pembentukan karakter siswa MIN 2 Lombok Tengah adalah:

1. Jadwal piket kelas

Srtategi pembentukan karakter siswa peduli lingkungan yang diterapkan di MIN 2 Lombok Tengah memberikan dampak yang baik untuk peserta didik, jadwal piket kelas memberikan pendidikan akan pentingnya tugas dan tanggung jawab yang telah diberikan. Bekerja sama merupakan titik awal untuk menumbuhkan sikap gotong royong, selain itu mengajarkan sejak dini akan pentingnya menjaga kebersihan, akan kebersihan peserta didik untuk hidup bersih dimanapun dan kapanpun. ${ }^{7}$

Piket kelas adalah suatu kegiatan yang dilakukan oleh siswa untuk membersihkan dan merapihkan tempat belajar mereka, yakni kelas mereka sendiri. Piket kelas biasanya dibentuk oleh masing-masing anggota kelasnya. Piket kelas terjadwal dan tersusun secara rapi. Piket dilakukan sebelum dan setelah kegiatan belajar mengajar berlangsung. Piket ini terbagi menjadi beberapa kelompok berdasarkan hari aktif kegiatan belajar mengajar. Daftar nama pembagian piket biasanya terpampang di dinding kelas dan dihias sedemikian rupa agar menarik.

Siswa perlu dilibatkan dalam kegiatan kebersihan sekolah, khususnya dalam lingkup kecil, yakni kelas. Melalui piket kelas, siswa akan belajar mengenai tanggung jawab, disiplin, dan peduli. Keterlibatan siswa dalam kegiatan kebersihan bertujuan untuk membiasakan diri bertanggung jawab membuang sampah pada tempatnya. Kebiasaan ini akan membekas setelah mengalami proses internalisasi secara intensif melalui piket kelas yang dilaksanakan setiap minggu secara bergiliran.

Kegiatan piket kelas akan membuat siswa semakin akrab dan kompak dengan temantemannya. Piket kelas dapat membantu siswa untuk saling mengenal satu sama lain. Di samping itu, siswa juga belajar membiasakan diri dengan aktivitas menyapu dan mengepel. Mungkin saja ada siswa yang bahkan belum pernah menyapu dan mengepel di rumahnya. Maka, piket kelas akan menjadi pengalaman pertama dan berharga bagi siswa.

Piket kelas yang dilakukan oleh siswa harus mendapat pengawasan dan perhatian dari pihak sekolah. Artinya, siswa tidak dibiarkan merawat dan menjaga kebersihan kelas tanpa adanya kontrol dari pihak sekolah. Pemeriksaan secara berkala harus tetap dilakukan oleh petugas kebersihan.

\footnotetext{
${ }^{7}$ Aminah, wawancar 18-04-2019
} 
2. Memantau kegiatan siswa.

Pembentukan karakter siswa untuk menjaga lingkungan di MIN 2 Lombok Tengah memberikan dampak yang baik untuk peserta didik, memantau kegiatan siswa di luar kelas mapun dilingkungan sekolah merupakan hal yang sangat positif. Memantau kegiatan siswa secara lasung memberikan motifasi kepada siswa untuk selalu memperhatikan kebersihan lingkungannya.

Kegiatan yang dilakukan oleh siswa di ruang kelas pada jam pembelajaran maupun jam istirahat mendapat pantuan oleh Pendidik khususnya wali kelas. Pada proses pembelajaran, pendidik memantau perkembangan siswa, tingkat kemampuan siswa bisa menyerap materi yang sedang dibahas, tingkat kemampuan siswa bekerja secara berkelompok.

Tujuan pemantauan siswa pada proses pembelajaran, untuk mencari solusi terhadap permasalahan yang timbul pada setiap siswa. Dengan demikian, masalah-masalah dalam proses pembelajaran teratasi dan kelas menjadi tenteram.

Selain pemantauan pada proses pembelajaran, pemanatauan siswa juga dilakukan ketika jam istirahat, hal ini dilakukan untuk mengetahui tingkat keaktifan siswa, toleransi siswa dan tenggang rasa siswa terhadap siswa lain.

3. Menyediakan tempat sampah/bak sampah

Sampah adalah suatu bahan yang terbuang atau dibuang dari sumber hasil aktivitas manusia maupun proses alam yang belum memiliki nilai ekonomis.

Dengan menyediakan tempat pembuangan sampah atau bak sampah, siswa bisa lebih menjaga lingkungan kelas dan lingkungan sekolah. Bak sampah yang disediakan di setiap kelas memiliki warna yang berbeda sesuai peruntukkannya. Siswa diberi pengetahuan tentang sampah dan bahaya sampah terhadap lingkungan dan bahaya sampah terhadap kesehatan.

Dengan adanya pengetahuan tentang sampah, siswa bisa menjaga dan melestarikan lingkungan, selain itu siswa bisa memilah sampah organik anorganik. Dengan pengenalan ini diharapkan siswa menjadi karakter yang cinta alam dan kebersihan sejak dini.

Dengan menambahkan sarana tempat pembungan sampah disetiap kelas memberikan dampak positif di MIN 2 Lombok Tengah, karna dengan menambahkan sarana tempat pembuangan sampah siswa lebih mudah untuk menjaga lingkungan agar tetap bersih.

\section{Gotong royong}

Kata gotong royong berasal dari bahasa jawa yaitu, gotong dan royong. "Gotong" artinya pikul atau angkat, "royong" artinya bersama-sama, jadi gotong royong artinya mengangkat beban secara bersama-sama agar beban menjadi ringan. Konsep gotong royong juga dapat dimaknai dalam konteks pemberdayaan masyarakat, karna bisa menjadi modal sosial untuk membantu kekuatan kelembagaan ditingkat komunitas, Masyarakat Negara serta 
Masyarakat Lintas Bangsa dan Negara Indonesia dalam mewujudkan kesejahteraan. Hal tersebut juga dikarenakan didalam gotong royong tergantung makna yang sangat penting untuk saling membantu sesama.

Sebagai makhuluk sosial, manusia mempunyai nurani untuk senantiasa berhubungan dengan manusia yang lainnya.hubungan yang sinambung tersebut, menghasilakn pola pergaulan yang dinamakan pola intraksi sosial. Yang salah satunya intraksi sosial yaitu: bekerja sama dan untuk melakukan suatu perbuatan sehingga apa yang dikerjakan bersama akan mudah untuk menyelesaikan pekerjaan seperti membersihkan lingkungan sekolah, lingkungan masyarakat dan lingkungan sekitar kita. ${ }^{8}$ Ketika gotong royong menjadi penciri dari kreatif lokal bangsa Indonesia yang menujukan kohesi sosial, masihkah gotong royong tersebut masih tumbuh dan berkembang dimasa ini? Manakala harus globalisasi tidak terbendung lagi dan manakala masyarakat terkotak-kotak dalam sebuah komunitas sesuai keberniatan mereka. Bisa kontak sosial dan komunikasi. ${ }^{9}$ Mengutip pandangan gotong royong akan selalu ada dalam peradaban manusia, hingga masyarakat memahami bahwa gotong royong tidak hanya sekedar aktifitas fisik, namun lebih pada solidaritas manusiawi.

\section{Kepedulian Guru dalam Pembentukan Karakter Siswa Peduli Lingkungan}

Peduli lingkungan adalah sikap dan tindakan yang selalu berupaya mencegah kerusakan pada lingkungan alam di sekitarnya dan mengembangkan upaya-upaya untuk memperbaiki kerusakan alam yang sudah terjadi. ${ }^{10}$ Penanaman sikap peduli lingkungan adalah usaha penanaman dan penumbuhkembangan sikap atau watak untuk peduli terhadap lingkungan yang kita diami dengan berbagai kegiatan seperti jum'at bersih, ekstrakurikuler PLH, mata pelajaran PLH, pemanfaatan limbah, pembuatan biopori dan lain sebagainya.

Lingkungan pendidikan, selain harus bersih, rapi juga semestinya dijaga keindahannya. Islam mengajarkan tentang kebersihan, kerapian, dan juga keindahan. Oleh sebab itu semestinya tidak boleh sekolah, madrasah, dan perguruan tinggi Islam menampakkan kekumuhan.Merawat kebersihan sebenarnya tidak selalu memerlukan biaya mahal. Asalkan mereka, yang bertanggung jawab, memiliki kepekaan atau terbiasa hidup bersih, maka akan merasa risih manakala lingkungannya tampak kotor. Oleh karena itu, kebersihan hanya terkait dengan kepekaan dan kemauan orang-orang yang bertanggung jawab terhadap lingkungan. ${ }^{11}$

Adapun kepedulian guru dalam pembentukan karakter siswa peduli lingkungan di MIN 2 Lombok Tengah adalah:

\footnotetext{
${ }^{8}$ Baharudin, sosiologi dan pendidikean, (pandan wangi: lengge printika, 2008), h. 62

9 Soerjono soekanto, sosiologi suatu pengantar. (PT rajawali pres: Jakarta, 2012), h. 55

10 Muhammad Fadlillah Dan Lilif Mualifatu Khorida, Pendidikan Karakter Anak Usia Dini (Jogjakarta: Aeruzz Media,2013) h. 201.

${ }^{11}$ Imam Suprayogo, Pengembangan Pendidikan Karakter (Malang: Uin Maliki Press,2013), h. 45.
} 
1. Menasehati atau motivasi

Startegi guru dalam pembentukan karakter siswa peduli lingkungan yang di terapkan di MIN 2 Lombok Tengah memberikan dampak yang baik untuk pesrta didik, menasehati memberikan dorongan untuk selalu menjaga lingkungan sekolah. Memberikan motifasi membuat peserta didik lebih bersemangat untuk mengerjakan pekerjaan yang diberikan oleh guru, dengan cara memberikan motifasi siswa merasa lebih diperhatikan. ${ }^{12}$

Menasehati atau memberikan motifasi kepada siswa merupakan suatu tindakan yang harus dilakukan untuk mengubah karakter siswa agar menjaga lingkungan sekolahnya agar tetap bersih dan sehat, karna dengan menasehati dan memberikan pengatahuan untuk menjaga lingkungannya siswa bisa berfikir ketika mereka membuang sampah tidak pada tempatnya. Pada dasarnya motivasi adalah suatu proses yang mendorong atau mempengaruhi seseorang untuk mendapatkan atau mencapai apa yang diinginkannya baik itu secara positif maupun negatif. Motivasi akan memberikan perubahan pada seseorang yang muncul akibat dari perasaan, jiwa dan emosi sehingga mendorong untuk melakukan tindakan sesuatu yang disebabkan karena kebutuhan, keinginan dan tujuan tersebut.

\section{Pendekatan}

Pentingnya pendekatan dalam sebuah perubahan untuk mengubah karakter peserta didik untuk menjaga lingkungan tetap bersih, Pendekatan yang dilakukan guru untuk mengubah karakter siswa di MIN 2 Lombok Tengah membawa perubahan yang sangat baik, dengan cara mendekati guru bisa mengetahui permasalahan yang dihadapi oleh siswa dan mengubah karakter yang kurang baik. ${ }^{13}$

Pendekatan berasal dari bahasa inggris approach yang diartikan pendekatan. Di dalam dunia pengajaran, kata approach lebih tepat diartikan a way of beginning something (cara mulai sesuatu). ${ }^{14}$

Pendekatan yang dilakukan guru terhadap siswa yang melakukan kesalahan bisa merubah sikap yang tidak peduli lingkungan menjadi peduli terhadap lingkungannya pendekatan yang dilakukan guru untuk menjaga lingkungan agar tetap bersih merupakan strategi yang sangat bagus untuk megubah karakter anak. Pendekatan lingkungan alam sekitar sebagai pendidikan di luar ruangan kelas yang berkaitan dengan penggunaan/pemanfaatan sumber daya alam. Alam sekitar sebagai fundamen pendidikan dan pengajaran memberi dasar emosional, sehingga anak menaruh perhatian yang spontan terhadap segala sesuatu yang diberikan kepadanya asal itu didasarkan atas dan diambil dari

12 Aminah, wawancara 20-04-2019

13 Arpan , wawancara 20-04-2019.

14 Nina, (2014, juni 11). Macam-macam pendekatan pembelajaran. Dipetik april 19, 2019 dari fun knowledge: http://sakinahniaarz009.blogspot.co.id. 
alam sekitar. pendekatan lingkungan sekitar dapat diartikan sebagai proses belajar mengajar yang berorientasi kepada dan berlangsung di lingkungan alam sekitar. ${ }^{15}$

Macam-macam pendekatan, yaitu (a) Pendekatan kontekstual, belatar belakang bahwa siswa belajar lebih bermakna dengan melalui kegiatan mengalami sendiri dalam lingkungan alamiah. (b) Pendekatan konstruktivisme merupakan landasan berfikir pendekatan konstektual, yaitu bahwa pendekatan dibangun oleh manusia sedikit demi sedikit yang hasilnya diperluas melalui konteks yang terbatas dan tidak dengan tiba-tiba. ${ }^{16}$

\section{SIMPULAN}

Berdasarkan pembahasan di atas, ditarik suatu kesimpulan mengenai strategi guru dalam pembentukan karakter siswa MIN 2 Lombok Tengah, bahwa para guru telah menggunakan startegi yang sangat baik dalam membangun karakter siswa untuk peduli lingkungan. Strategistrategi yang telah diterapkan oleh guru dapat menjadikan siswa menjaga lingkungan sekolah/kelas dengan baik. Strategi guru yang dimaksud, antara lain, (1) Penetapan jadwal piket kelas; setiap kelas mempunyai jadwal piket untuk menjaga lingkungan kelasnya agar kelas dan lingkungan sekolahnya tetap bersih dan indah serta kegiatan yang dilakukan oleh siswa yang membersihkan dan merapikan tempat belajar mzereka. (2) Observasi atau memantau secara langsung kegitan siswa. Para guru ikut serta bersama siswa, mengawasi, memantau dan menjadi contoh yang baik untuk siswa, karna itu adalah salah satu kunci agar kami dapat memberikan contoh perilaku yang baik kepada siswa dalam menjaga lingkungan kelas agar tetap bersih dengan cara menyapu kelas, membersihkan kolom meja, mengelap kaca dan lain sebaginya. (3) Menambah tempat pembuangan sampah/bak sampah. Dengan menambahkan tempat pembuangan sampah atau bak sampah siswa bisa lebih menjaga lingkungan kelas dan lingkungan sekolahnya, dan bisa mengelola sampah menjadi sebuah hiasan kelas seperti, botol, gelas plastik dan guru memanfaatkan sampah yang bisa digunakan. (4) Gotong royong dalam kegiatan gotong royong. Para guru mengajarkan kepada siswa untuk bisa bekerjasama dan saling membantu satu sama lain dengan teman-teman sekitarnya dalam kegiatan pembersihan lingkungan sekolah supaya mereka bersama-sama dalam menjaga lingkungan sekolah dengan kebersihan mereka dapat bermain dan belajar dengan nyaman di lingkungan yang bersih.

Kepedulian guru dalam pembentukan karakter siswa peduli lingkungan tergambar dalam menasehati atau memberikan motifasi kepada siswa suatu tindakan yang harus dilakukan untuk mengubah karakter siswa agar menjaga lingkungan sekolahnya agar tetap bersih dan sehat, karna dengan menasehati dan memberikan pengatahuan untuk menjaga

${ }^{15}$ Barlia, Lily. Mengajar dengan Pendekatan Lingkungan Sekitar, (Subang: Royyan Press, 2008), h. 4-5

16 Suhandoyo, Upaya Meningkatkan Kualitas Sumber Daya Manusia Melalui Interaksi Positif Dengan Lingkungan, (Yogyakarta: PPM IKIP Yogyakarta, 1993), h. 20 
lingkungannya siswa bisa berfikir ketika mereka membuang sampah tidak pada tempatnya. Di mana juga motivasi terjadi pada diri seseorang baik dalam dirinya sendiri atau di luar diri sendiri dengan teman sebaya dan lingkungan yang memberikan semangat dan motivasi untuk melakukan pekerjaan yang berdampak positif pada diri sendiri dan lingkungannya. Pendekatan pendekatan yang dilakukan guru untuk menjaga lingkungan agar tetap bersih kami bisa memberikan pendekatan dengan pengarahan yang baik bagi siswa, dengan Pendekatan lingkungan sekitar sebagai pendidikan di luar ruangan kelas yang berkaitan dengan penggunaan atau pemanfaatan sumber daya alam sekitar sebagai fundamen pendidikan dan pengajaran memberi dasar emosional, sehingga anak menaruh perhatian yang spontan terhadap segala sesuatu yang diberikan kepada siswa yang diambil dari alam sekitar. pendekatan lingkungan sekitar dapat diartikan sebagai proses belajar mengajar yang berlangsung di lingkungan alam sekitar atau lingkungan sekolah.

\section{DAFTAR PUSTAKA}

Anas, Salahudin. 2013. Pendidikan Karakter. Bandung: Pustaka Setia.

Aqib, Zainal. 2012. Panduan Dan Aplikasi Pendidikan Karakter. Bandung: Yrama Widya.

Azzet, Ahmad Mauhaimin. 2011. Urgensi Pendidikan Karakter di Indonesia. Jogjakarta: Ar-Ruzz Media.

Basrowi dan Suwandi. 2008. Memahami Penelitian Kualitatif. Jakarta: Rineka Cipta.

Djamarah, Syaiful Bahri dan Aswan Zain. 2010. Strategi Belajar Mengajar. Jakarta: Rineka Cipta. Hamalik, Oemar. 2014. Kurikulum Dan Pembelajaran. Jakarta: Bumi Aksara.

Hamzah, Mohamad Nurdin. 2015. Belajar Dengan Pendekatan Pembelajaran Aktif Inofatif Lingkungan Kreatif Efektif Menarik. Jakarta: Bumi Aksara.

Hendri. 2013. Pendidikan Karkter Berbasis Dongeng. Bandung: Remaja Rosdakarya.

Kadir, Abdul. 2012. Dasar Dasar Pendidikan. Jakarta: Kencana Prenadamedia Group.

Lickona, Thomas. 2013. Mendidik Untuk Membentuk Karakter. Jakarta: Bumi Aksara.

Listyarti, Retno. 2012. Pendidikan Karakter. Jakarta: Erlangga Group.

Made, Pidarta. 2004. Manejemen Pendidikan Indonesia. Jakarta: Rineka Cipta.

Mahmud. 2011. Metode Penelitian Pendidikan. Bandung: Pustaka Setia.

Mansur, Muslic. 2011. Pendidikan Karakter Menjawab Tentang Krisis Mulitidimensional. Jakarta: Bumi Aksara.

Mariyana, Rita. 2010. Pengelolaan Lingkungan Belajar. Jakarta: Prenada Media.

Masnur, Muslich. 2014. Pendidikan Kkarakter Jakarta: Bumi Aksara.

Muwafik, Saleh. 2011. Membangun Karakter Dengan Hati Nurani. Malang: Erlangga Group.

Saefullah. 2012. Psikologi Perkembangan Dan Pendidikan. Bandung: Pustaka Setia.

Sugiyono. 2015. Metode Penelitian Kuantitatif, Kualitatif Dan R\&D. Bandung: Alfabeta. 
Tirtaraharja, Umar Lasulo. 2005. Pengantar Pendidikan. Jakarta: Rineka Cipta.

Yaumi, Muhammad. 2014. Pendidikan Karakter, Landasan, Pilar, dan Implementasi. Jakarta: Premadia Group.

Yusuf, Syamsul. 2011. Psikologi Perkembangan Anak Dan Remaja. Bandung: Remaja Rosdakarya. Zubaedi. 2013. Desain Pendidikan Karakter. Jakarta : Prenada Media Group.

Zubaidi. 2011. Desain Pendidikan Karakter Konsep dan Aplikasi dalam Lembaga Pendidikan. Jakarta: Kencana. 